\title{
Climate Change Over the Himalayas
}

\section{Coordinating Lead Authors}

T. P. Sabin, Indian Institute of Tropical Meteorology (IITM-MoES), Pune, India, e-mail: sabin@tropmet.res.in (corresponding author)

R. Krishnan, Indian Institute of Tropical Meteorology (IITM-MoES), Pune, India

\section{Lead Authors}

Ramesh Vellore, Indian Institute of Tropical Meteorology (IITM-MoES), Pune, India P. Priya, Indian Institute of Tropical Meteorology (IITM-MoES), Pune, India H. P. Borgaonkar, Indian Institute of Tropical Meteorology (IITM-MoES), Pune, India Bhupendra B. Singh, Indian Institute of Tropical Meteorology (IITM-MoES), Pune, India Aswin Sagar, Indian Institute of Tropical Meteorology (IITM-MoES), Pune, India

\section{Review Editor}

Anil Kulkarni, Indian Institute of Science, Bangalore, India

\section{Contributing Authors}

Thamban Meloth, National Centre for Polar and Ocean Research (NCPOR-MoES), Goa, India Paramanand Sharma, National Centre for Polar and Ocean Research (NCPOR-MoES), Goa, India M. Ravichandran, National Centre for Polar and Ocean Research (NCPOR-MoES), Goa, India Mahesh Ramadoss, Indian Institute of Tropical Meteorology (IITM-MoES), Pune, India

\section{Corresponding Author}

T. P. Sabin, Indian Institute of Tropical Meteorology (IITM-MoES), Pune, India, e-mail: sabin@tropmet.res.in 


\section{Key Messages}

- The Himalayas and the Tibetan Plateau have experienced substantial warming during the twentieth century. The warming trend has been particularly pronounced over the Hindu Kush Himalaya (HKH) which is the largest area of permanent ice cover outside the North and South Poles.

- The annual mean surface-air-temperature in the HKH increased at a rate of about $0.1{ }^{\circ} \mathrm{C}$ per decade during 1901-2014, with a faster rate of warming of about $0.2^{\circ} \mathrm{C}$ per decade during 1951-2014, which is attributable to anthropogenic climate change (High confidence). Additionally, high elevations ( $>4000 \mathrm{~m}$ ) of the Tibetan Plateau have experienced stronger warming, as high as $0.5^{\circ}$ $C$ per decade, which is commonly referred to as elevation-dependent warming (EDW).

- Several areas in the HKH have exhibited declining trends in snowfall and retreating glaciers during the recent decades. Parts of the high-elevation Karakoram Himalayas have, in contrast, experienced increased wintertime precipitation in association with enhanced amplitude variations of synoptic western disturbances (Medium confidence).

- Future climate projections under various CMIP5 scenarios suggest warming of the $\mathrm{HKH}$ region in the range of $2.6-4.6^{\circ} \mathrm{C}$ by the end of the twenty-first century. While future projections indicate significant decrease of snowfall in several regions of the $\mathrm{HKH}$, high-elevation locations $(>4000 \mathrm{~m}$ ) in the Karakoram Himalayas are projected to experience an increase in annual precipitation during the twenty-first century.

\subsection{Introduction}

The name "Himalaya" means "the abode of snow" in Sanskrit. The continental drift theory suggests that the Himalayas were formed about 50 million years ago when the Indian plate collided with the Eurasian plate (Kious and Tilling 1996). The large spatial extent of the Himalayas (Fig. 11.1) spans across eight countries of the Asian continent and is the source of ten major river systems (Sharma et al. 2019, HIMAP) providing water for drinking, irrigation and power for over 1.3 billion people in Asia-which is nearly $20 \%$ of the world's population (e.g. Bookhagen and Burbank 2006; Rashul 2014). The Himalayan mountain range is the world's tallest and is notably the home to 10 of the 14 world's highest peaks, while the Karakoram and the Hindu Kush are generally viewed as separate ranges in the literature (Godin et al. 1999). The area that encompasses the Hindu Kush Himalaya (HKH) mountain range and the
Tibetan Plateau (TP) is popularly known as the "Third Pole" as it contains the largest reserve of freshwater outside the north and south poles. The meltwater generated from the Himalayan glaciers supplies the rivers and streams of the region, including the Indus, Ganges and Brahmaputra river systems of India. These rivers collectively provide about $50 \%$ of the country's total utilisable surface water resources (Srivastava and Misra 2012). Scientific evidence also shows that most glaciers in the HKH region are subjected to loss in volume and mass under the propensity of rising temperatures due to climate change (Kulkarni and Karyakarte 2014; ICIMOD 2007, 2011; Armstrong 2011; Wester et al. 2019; IPCC SROC 2019). Yet, a clear understanding and quantification of its consequences in these mountain ranges remain challenging.

The climate of the HKH is characterised by tropical/subtropical climatic conditions from the foothill region of the mountains to permanent ice and snow-covered peaks at higher altitudes (Pant et al. 2018). Flora and fauna of the Himalayas vary with climate, rainfall, altitude and soils. The amount of annual rainfall increases from west to east along the southern front of the range. Further, the Himalaya is delineated by different climatic sub-zones due to diverse geographical variability, which is closely linked to topographical distribution of the region (Bookhagen and Burbank 2006). The annual cycle of temperature and precipitation differs substantially in these different zones. Seasonal variations in the mean climate of HKH are closely tied to the seasonal cycle of the regional atmospheric processes (Box 11.1).

The valleys experience mean summer temperatures between 15 and $25^{\circ} \mathrm{C}$ and much colder in winter. Regions with elevations above $4500 \mathrm{~m}$ experience severe winter, with temperatures far below freezing point and precipitation in the form of snow, e.g. the Karakoram range of the Himalayas experiences an average maximum temperature of about $20^{\circ} \mathrm{C}$ during the summer, and average minimum temperature goes below $-3{ }^{\circ} \mathrm{C}$ in February (Hasson et al. 2014; Kapnick et al. 2014). The north-western peaks of Himalayas typically experience dry conditions, with surface temperatures ranging between 3 and $35^{\circ} \mathrm{C}$ in summer and -20 and $-35{ }^{\circ} \mathrm{C}$ in winter together with heavy snowfall.

The climate of the HKH has been experiencing significant temperature changes since twentieth century where the warming trend during the first (second) half of the twentieth century was about $0.10{ }^{\circ} \mathrm{C}\left(0.16{ }^{\circ} \mathrm{C}\right)$ per decade, which later doubled to $0.32{ }^{\circ} \mathrm{C}$ per decade from the beginning of the twenty-first century (Yan and Liu 2014). The warming rate is reported to be more substantial in winter as compared to other seasons in most parts of the $\mathrm{HKH}$ region (Bhutiyani et al. 2007; Shrestha et al., 2010). Studies by Dimri and Dash (2012), Negi et al. (2018), etc., also confirm that most of the 
Fig. 11.1 Hindu Kush Himalayan $(\mathrm{HKH})$ region and the three sub-regions (rectangular black box) of interest: the northwest Himalaya and Karakoram (HKH1), central Himalaya (HKH2) and southeast Himalaya and Tibetan Plateau (HKH3)
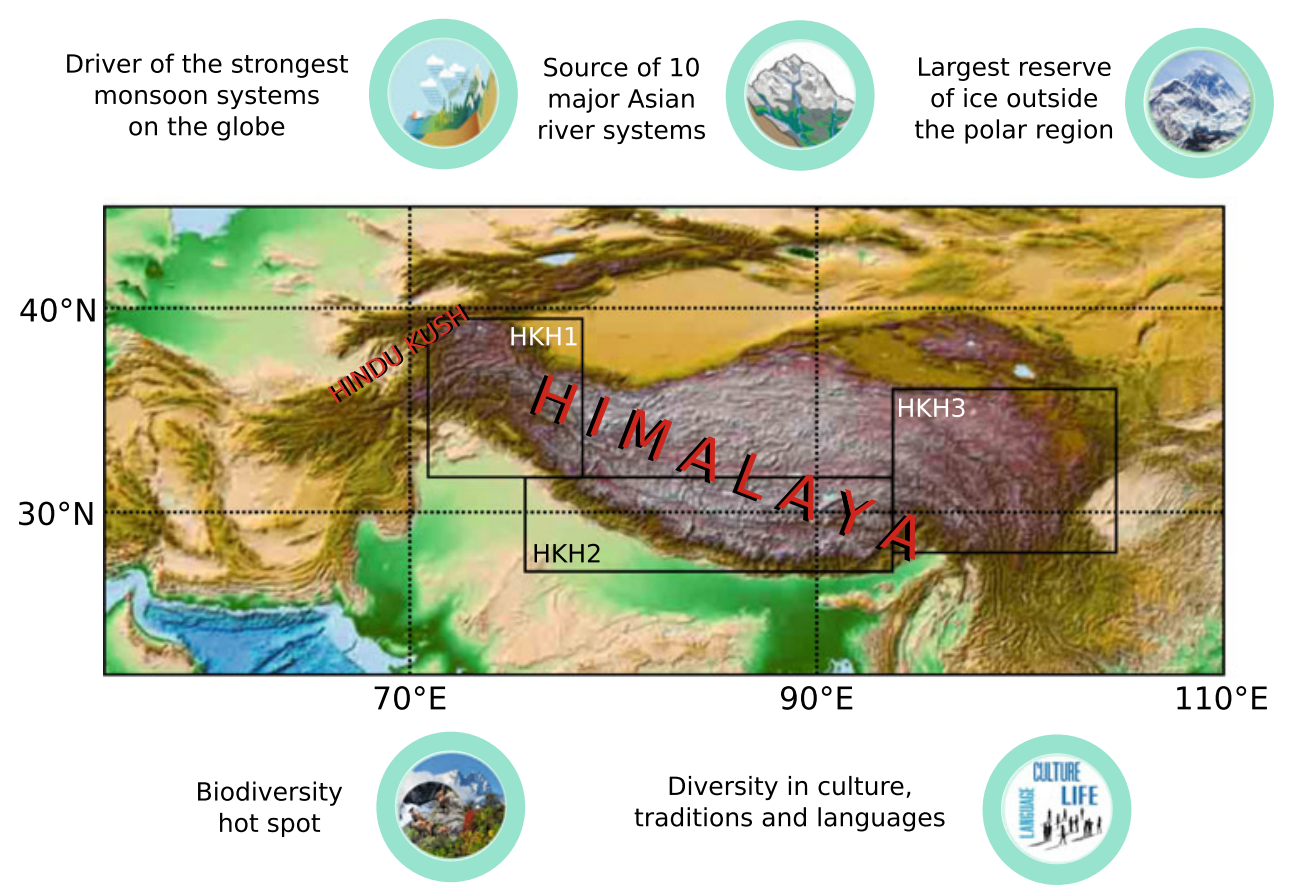

western Himalayan (WH) stations recorded a significant warming trend especially from 1975 onwards. This is also supported by tree-ring chronologies of the region which indicated rapid growth of tree rings in the recent decades especially at higher altitudes (Borgaonkar et al. 2009). This chapter provides an assessment of the current state of knowledge of the weather and climate aspects of the HKH region. Thematic assessments of socio-economic and other sectorial impacts are covered in the "Hindu Kush Himalaya Assessment report" (Wester et al. 2019) and the "IPCC Special report on Ocean and Cryosphere in a Changing Climate, Chapter 2: High Mountain Areas" (IPCC SROC 2019).

\section{Box 11.1 Weather and climate of Himalaya}

The HKH1 sub-region generally receives more precipitation during the winter months, while more than $80 \%$ of annual precipitation in the central and eastern sub-region (HKH 2 and 3) of the Himalayas is received during the summer monsoon season. The three major Himalayan river basins, viz. Indus, the Ganga and the Brahmaputra, receive an annual rainfall of about 435, 1094 and $2143 \mathrm{~mm}$, respectively (Shrestha et al. 2015). Weather dynamics is intricate in the Himalayan region arising due to extensive interactions of tropical and extra-tropical weather systems. Vellore et al. (2014) reported that heavy rainfall over the WH region during summer is often associated with the interaction between westward-moving monsoon low-pressure systems and subtropical westerly winds.
Precipitation during the winter months contributes nearly half of the annual precipitation over the Karakoram and the Hindu Kush Mountain ranges (Kapnick et al. 2014; Cannon et al. 2015; Hunt et al. 2018; Krishnan et al. 2019a). The accumulation of snow occurs during the winter months which is the primary water reserve for the subsequent dry periods (Lang and Barros 2004; Rees and Collins 2006; Immerzeel et al. 2010; Bolch et al. 2012; Hasson et al. 2013). The western side of the Karakoram Himalaya is prone to large amounts of snowfall in winter from frequent passage of midlatitude synoptic-scale systems known as the western disturbances (Dimri et al. 2015; Madhura et al. 2015; Cannon et al. 2015; Krishnan et al. 2019a). Tropical and extra-tropical climate drivers such as the El Niño-Southern Oscillation (ENSO; Diaz and Markgraf 2000), North Atlantic Oscillation (NAO; Branstator 2002), Madden-Julian Oscillation (MJO; Madden and Julian 1971), Arctic Oscillation (AO; Thompson and Wallace 1998; Wallace 2000) and the Indian Ocean Dipole mode (IOD; Saji et al. 1999) generally appear to exert significant influence in regulating the weather and climate of the $\mathrm{HKH}$ region (see Barlow et al. 2005; Bhutiyani et al. 2009; Cannon et al. 2017). More details on these aforesaid teleconnection patterns can be seen in Panagiotopoulos et al. (2002) and Sheridan et al. (2012). Archer and Fowler (2004) also note that there is an in-phase relation between NAO and precipitation variability over the 
Karakoram Himalayas during winter months. It is also widely accepted that there is a significant role of $\mathrm{HKH}$ and TP in maintaining the Asian summer monsoon circulation (Nan et al. 2009; Zhou et al. 2009), i.e., heating of the TP in summer raises air temperatures thereby enhancing the pressure gradient which drives the South Asian summer monsoon, and therefore, the HKH and TP act as a major heat sink (source) during the winter (summer) (Yanai and Li 1994). The presence of the HKH topographical barrier restricts the upper-level subtropical westerly winds to regions poleward of $30^{\circ} \mathrm{N}$ during the boreal summer months, thereby allowing warm and moist summer monsoon circulation to extend northward into the Indian subcontinent. Observations and model simulations clearly suggest that the Himalayan orography has an important role in maintaining the South Asian monsoon circulation by insulating warm, moist air over continental India from the cold and dry extra-tropics (Chakraborty et al. 2006; Krishnan et al. 2009; Krishnamurti et al. 2010; Boos and Kuang 2010; Turner and Annamalai 2012; Sabin et al. 2013).

\subsection{Observed Trends in Mean Surface Temperature and Precipitation}

Significant rise in surface temperatures is noted throughout the HKH region during the past six decades (see Kulkarni et al. 2013; Rajbhandari et al. 2016). The warming was reported progressively over the western and eastern Himalayan river basins, and the long-term trend of minimum temperatures is noted slightly higher than the trend seen in maximum temperatures (Rajbhandari et al. 2015). Using century-long historical time series, Ren et al. (2017) showed that there were epochs of rise and fall in temperature trend over the HKH region, i.e., mean temperature exhibited a moderate rising trend from 1901 to the early 1940s, while a falling trend is seen between 1940 and 1970 followed by a rapid warming. The spatial pattern of trends of annual mean temperatures over the $\mathrm{HKH}$ region during the 1901-2014 period shows that the warming rates were more than $0.3{ }^{\circ} \mathrm{C}$

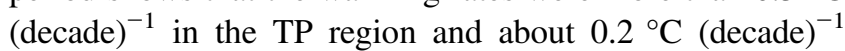
over the eastern side of the HKH range (Ren et al. 2017). It can also be noted that most of the grids consistently showed a positive trend in the annual warming signal; however, the warming rates are significantly different. Various studies attributed this observed warming signal to the increase in anthropogenic greenhouse gas concentrations (IPCC 2007, 2013; You et al. 2017).
Pepin et al. (2015) show that mountain temperatures are increasing at a faster rate than the global average. We have further noted that the Himalayas are also warming at a faster rate than that of the nearby Indian land mass. Figure 11.2 shows the annual mean temperature time series averaged over HKH and Indian land mass from 1951 to 2018, which is indicating a warmer Himalaya comparing to the Indian land mass. Further, the observations also reveal that the recent warming rates are not seen to be uniform over the HKH region where the annual average warming rates change with altitudes which are commonly referred as the elevation dependency of climate warming (EDW) (e.g. Liu et al. 2009; Ren et al. 2017; Shrestha et al. 1999; Thompson et al. 2003). Figure 11.3 shows the trend per decade for different altitude sectors of HKH. Low-elevation sites $(<500 \mathrm{~m})$ show a slower warming rate $\left(<0.2{ }^{\circ} \mathrm{C}\right.$ per decade $)$ as compared to high elevations $(>2000 \mathrm{~m})$ of the eastern TP where higher warming rate $\left(0.61{ }^{\circ} \mathrm{C}\right.$ per decade $)$ is seen during the past few decades (Liu et al. 2009; Ren et al. 2017). Northern India and the Sichuan Basin of China showed the weakest warming trend with annual warming rates less than $0.10{ }^{\circ} \mathrm{C}$ (decade $)^{-1}$, as well as the Karakoram range during the northern summer (Forsythe et al. 2017).

The spatial distribution of the trends of annual precipitation based on APHRODITE dataset during 1951-2015 is shown in Fig. 11.4. The observed map of trend in the annual mean precipitation depicts substantial spatial heterogeneity over the HKH region (Fig. 11.4). While there is a subtle rise in the precipitation trend over the Karakoram and Western Himalayas and the eastern part of Himalayas, a declining trend can be noticed over many areas. A wet trend is evident over northwest China, including the TP (Ren et al. 2015; You et al. 2015). The triangular markings in Fig. 11.4 correspond to precipitation trends per decade based on CMA-GMLP dataset for a longer period for 1901-2013. Both the datasets show consistency in precipitation enhancement over $\mathrm{WH}$ and decline over central and north Indian plains. The reduction in annual precipitation over northern India is also consistent with the reported declining trend of the Indian summer monsoon precipitation during the post-1950 (Krishnan et al. 2013, 2016).

Recent observational studies also suggest that there is an increasing trend in the number of wet days over the $\mathrm{WH}$ during the past few decades (Klein Tank et al. 2006; Choi et al. 2009). It has been reported that increases in wintertime heavy precipitation over the Karakoram region of northwest Himalayas and falling precipitation trend over Central Himalayas $(\mathrm{CH})$ are linked to an increasing trend in the synoptic-scale activity of the western disturbances (WDs), while the $\mathrm{CH}$ region experiences a falling local precipitation trend (Cannon et al. 2015; Madhura et al. 2015; Krishnan 
HIMALAYA VS. INDIA

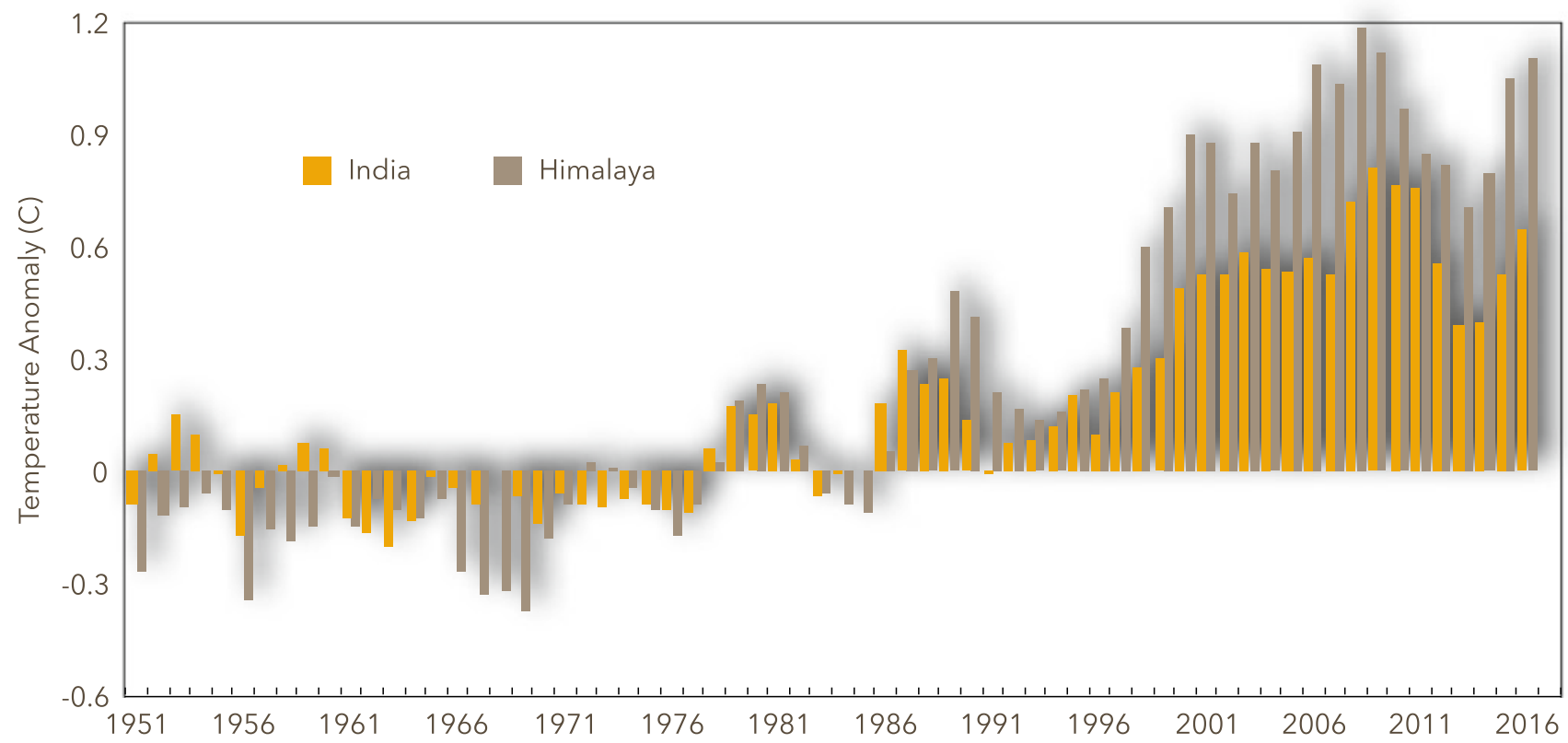

Fig. 11.2 Annual mean temperature time series (5-year running mean) averaged over HKH (grey) and Indian land mass (yellow) from 1951 to 2018

Fig. 11.3 Elevation-dependent warming over and around $\mathrm{HKH}$. Shown is the trend/decade of surface air temperature for respective altitude ranges

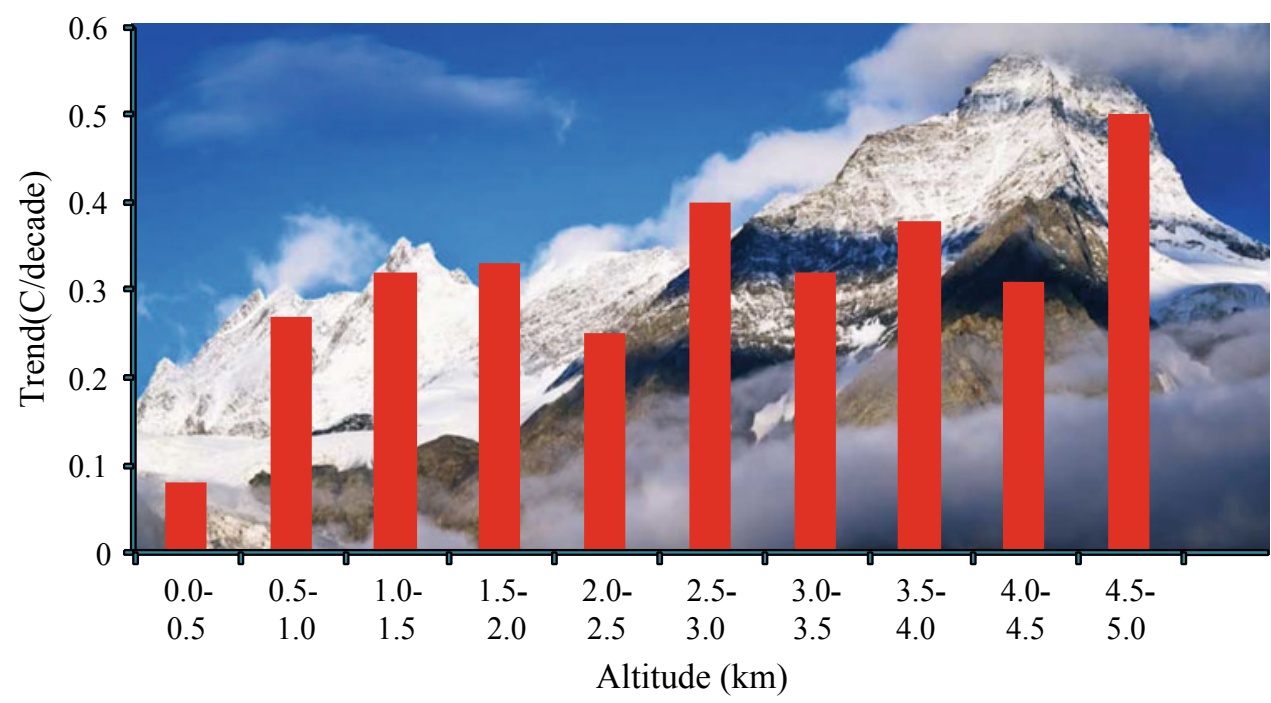

et al. 2019a). A few studies also attribute the increase in the mass of some glaciers in the Karakoram and Western Himalaya to changes in the WD activity (Forsythe et al. 2017). In contrast to other mountain peaks across the globe, which have largely experienced decreasing snowfall amounts and glacial extent during the recent decades, the Karakoram Himalayas appear to have slightly gained glacial mass in the early twenty-first century (Gardelle et al. 2012; Hewitt 2005; Kapnick et al. 2014).

\subsection{Observed Changes in Temperature and Precipitation Extremes}

Significant rise in extreme warm events and a substantial fall in extreme cold events observed over the HKH during the last few decades (e.g. Sun et al. 2017). In particular, the magnitude of trends in warm events is more significant than those of the cold events. A significant rise in the number of 


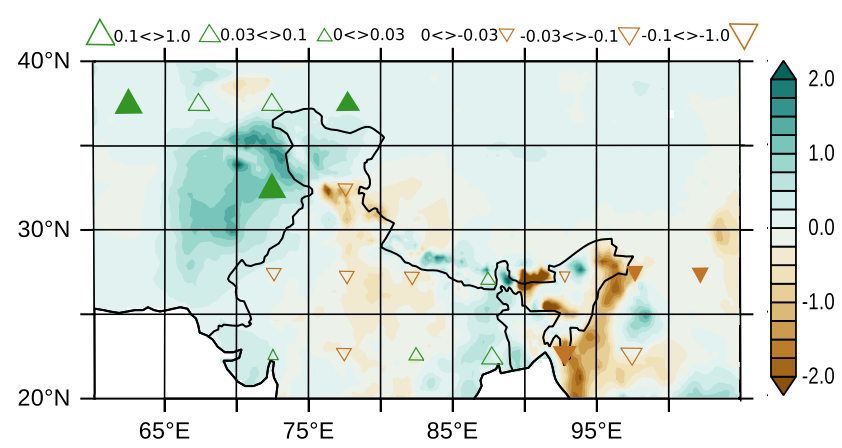

Fig. 11.4 Spatial pattern of linear trends in annual mean precipitation anomalies from APHRODITE data from 1951 to 2015. The triangles are from the trend per decade based on CMA-GMLP for 1901-2013 periods

warm nights (Tn90p) and a decrease in the number of frost days are seen from early-1990s (Fig. 2h-g of Sun et al. 2017). Throughout the HKH region, the annual mean diurnal temperature range (DTR) anomalies showed an apparent decline before 1980s, while DTR exhibits a rising trend after the mid-1980s. The spatial distribution of linear trends for extreme temperature indices indicate that extremely cold days and nights in the Tibetan Plateau (TP) region decreased by -0.85 and -2.3 days per decade, respectively, while the warm days and warm nights increased by 1.2 and 2.5 days per decade, respectively (Sun et al. 2017). The number of frost days and ice days is also seen to be decreasing significantly at a rate of -4.3 and -2.4 days per decade, respectively. Overall, the length of the growing season appears to have increased at a rate of 4.5 days per decade (Liu et al. 2006).

The frequency and intensity of observed precipitation extremes in the HKH region exhibit significant changes since the 1960s. Light precipitation amounts (below 50th percentile) show a significant rising tendency over northern TP and southern Tarim Basin, while there has been a declining trend over southwest China (Zhan et al. 2017). The intensity of light precipitation shows significant reductions over the northern part of the Hindu Kush and Central India (cf. Figs. 2 and 3 of Zhan et al. 2017). In addition, the frequency and intensity of heavy precipitation show significant increasing trends mostly over the TP, with opposite trends over southwest China, and South-Central Asia. Linear trends of regional average maximum 5-day consecutive precipitation (RX5DAY) index show a clear increasing trend over the HKH region by $2.3 \%$ per decade during 19612012. Consecutive wet days significantly increased over the Indian side of Himalayan and Karakoram ranges and moderate rise over most of the other locales of the TP. The spatial distribution pattern of consecutive dry-day trend is nearly opposite to that of consecutive wet days. In summary, several areas in the TP indicate a rising tendency in intense precipitation, whereas the change is heterogeneous over other areas of the HKH region.

\subsection{Future Projections Over HKH}

Precipitation from the summer monsoon rainfall is an important source of water for the river basins in the eastern and central HKH. River basins originating in the WH are predominantly fed by snow and glacial melt with precipitation largely coming from wintertime western disturbances (e.g. Bookhagen and Burbank 2006; Immerzeel et al. 2009; Lutz et al. 2014; Madhura et al. 2015; SAC 2016). The HKH region is warming at a much higher rate than the global mean (Shrestha et al. 2015; Van Vuuren et al. 2011). With continued global warming, future changes in temperature and precipitation are expected to alter the sensitive cryospheric processes over the HKH region substantially (Shrestha and Aryal 2011; Xu et al. 2008). Accelerated warming over the ice-covered mountain peaks and valleys exert profound impacts on the climate-dependent sectors like agriculture and water resources of the HKH region, thereby warranting a robust and reliable future outlook of the regional climate (Shrestha et al. 2015; Krishnan et al. 2019b; Sharma et al. 2019).

\subsubsection{Projected Changes in Mean Temperature and Precipitation}

Analysis of annual mean surface temperature projections based on the CMIP5 multi-models (Table 3.2b of Chap. 3) indicates an increase of temperature in the $\mathrm{HKH}$ region by $2.2 \pm 0.9^{\circ} \mathrm{C}\left(3.3 \pm 1.4^{\circ} \mathrm{C}\right)$ for the near future; $2040-2069$ (far future; 2070-2099) of the twenty-first century, following the RCP4.5 scenario. Under the extreme scenario $\mathrm{RCP} 8.5$, the temperature increase in the $\mathrm{HKH}$ region is projected to be $2.8 \pm 1.2{ }^{\circ} \mathrm{C}\left(4.8 \pm 1.7{ }^{\circ} \mathrm{C}\right)$ for the near future (far future) of the twenty-first century (Fig. 11.5a). Wintertime (DJF) temperatures are projected to increase by $2.4 \pm 1{ }^{\circ} \mathrm{C}\left(3.5 \pm 1.4{ }^{\circ} \mathrm{C}\right)$ for the near future (far future) of the twenty-first century, following RCP4.5. The corresponding wintertime temperatures for the two epochs under the RCP8.5 scenario are projected to increase by $3.1 \pm 1.4^{\circ}$ $\mathrm{C}\left(5.1 \pm 1.8^{\circ} \mathrm{C}\right)$, respectively (Fig. $11.5 \mathrm{~b}$ ).

Significant warming is projected over the $\mathrm{HKH}$ region in the near and far future, with prominent temperature increase projected over the Tibetan Plateau with magnitudes exceeding $5{ }^{\circ} \mathrm{C}$ under the RCP8.5 scenario by the end of the twenty-first century (Xu et al. 2014; Wu et al. 2017). The projected warming also differs by more than $1{ }^{\circ} \mathrm{C}$ between 


\section{a) Annual}
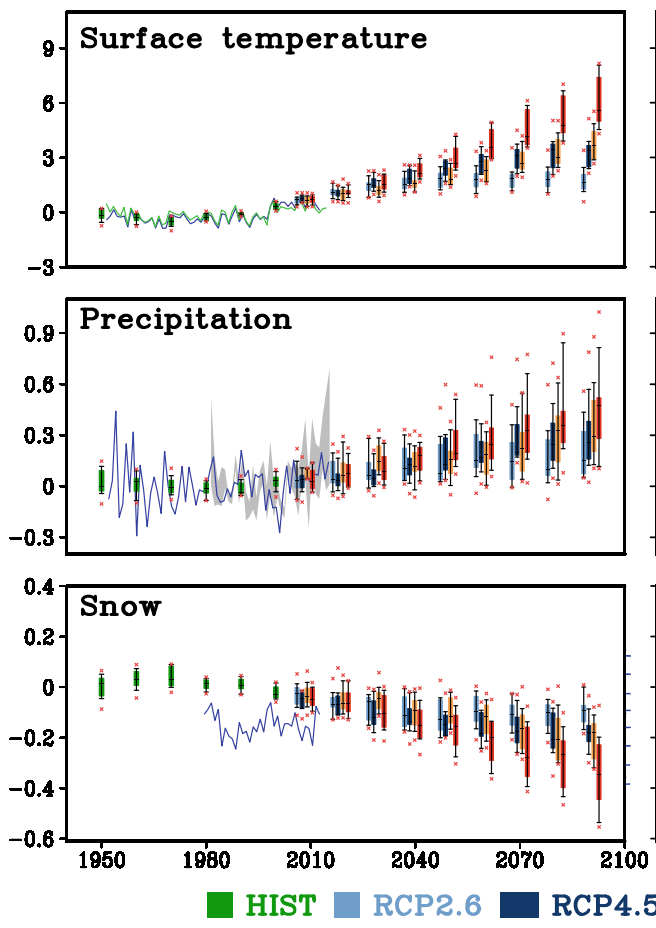

b) Winter
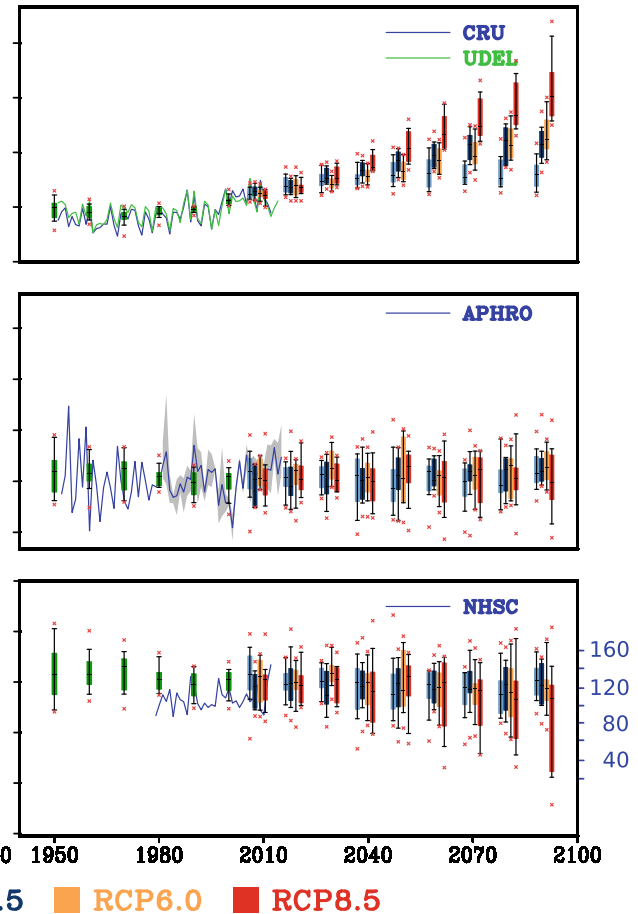

Fig. 11.5 Box whiskers of variations in surface air temperature $\left({ }^{\circ} \mathrm{C}\right)$, precipitation (mm/day) and snow (mm/day) over the HKH from the CMIP5 projections for the different future scenarios (Annual mean (a) and Winter season (b)). Variations in ten-year means, with respect to the reference period (1976-2005), are presented as box whiskers plots. Observed temperature (CRU) and precipitation (APHRODITE) are shown during 1951-2015. Precipitation from GPCP and CMAP are also shown during 1981-2015. Grey shade is the ensemble spread during 1981-2015. The snow cover observation is based on the NSIDC dataset from 1979 to 2012 (NHSC: Northern Hemisphere State of Cryosphere, right y-axis). Note that variations in observed snow cover extent are expressed in $x 10000 \mathrm{~km}^{2}$. The CMIP5 projected variations in snowfall are expressed in $\mathrm{mm} /$ day (left $\mathrm{y}$-axis)

Table 11.1 Projected changes in mean annual precipitation (\%) over HKH region with respect to 1976-2005 period

\begin{tabular}{l|l|l|l|l|}
\hline & Scenario & \multicolumn{4}{l}{ Spatial range of annual precipitation change (\%) } \\
\cline { 3 - 5 } & & CMIP5 & CORDEX & NEX \\
\hline \multirow{2}{*}{ Near future } & RCP4.5 & $2-8$ & $5-15$ & $5-20$ \\
\cline { 2 - 5 } & RCP8.5 & $4-15$ & $10-20$ & $5-25$ \\
\hline & RCP4.5 future & $5-15$ & $10-20$ & $15-25$ \\
\cline { 2 - 5 } & RCP8.5 & $10-20$ & $15-30$ & $20-40$ \\
\hline
\end{tabular}

the eastern and western $\mathrm{HKH}$, with relatively higher warming in winter based on the diagnosis from high-resolution CORDEX model outputs (Sanjay et al. 2017). The downscaled multi-RCMs analysis from CORDEX projection shows a significant warming over the $\mathrm{HKH}$ as a whole and its hilly sub-regions, with a projected change of $5.4{ }^{\circ} \mathrm{C}$ during winter and $4.9{ }^{\circ} \mathrm{C}$ during the summer season by the end of the twenty-first century under the high-end emissions (RCP8.5) scenario (Sanjay et al. 2017). Projected changes in annual mean temperature over the $\mathrm{HKH}$ region is also calculated using the Reliability Ensemble Approach (REA; Box 2.4) based on the CORDEX models. The near future (2040-2069) increase in annual mean temperature over the $\mathrm{HKH}$ is projected to be $2.26{ }^{\circ} \mathrm{C}$ $\pm 0.45{ }^{\circ} \mathrm{C}\left(3.2{ }^{\circ} \mathrm{C} \pm 0.58{ }^{\circ} \mathrm{C}\right)$ in the $\mathrm{RCP} 4.5$ (RCP8.5) scenarios, respectively. The corresponding projections for the two scenarios in the far future (2070-2099) are noted to be $2.76{ }^{\circ} \mathrm{C} \pm 0.61{ }^{\circ} \mathrm{C}\left(5.23{ }^{\circ} \mathrm{C} \pm 0.91{ }^{\circ} \mathrm{C}\right)$, respectively. The changes are relative to the baseline period (1976-2005).

Precipitation response to climate change is subject to greater uncertainties, as compared to temperature changes, particularly over the complex topographical terrains of HKH. To better understand projected changes in precipitation, we additionally used the multi-model ensemble (MME) from the high-resolution $\left(0.5^{\circ}\right.$ resolution $)$ dynamically downscaled CORDEX-SA models (Table 3.2a of Chap. 3; 16 members) 
and statistically downscaled NEX-GDDP $\left(0.25^{\circ}\right.$ resolution $)$ (marked in Table 3.2b of Chap. 3; 19 members) datasets. Future projections of precipitation over the $\mathrm{HKH}$, from the three approaches along with their spatial range in ensemble mean, are summarised in Table 11.1.

The projected precipitation changes are similar until the 2050s for both the RCP4.5 and RCP8.5 scenarios, with a higher increase after 2050 in RCP8.5. A box-whisker analysis is provided to demonstrate the projected changes based on CMIP5 models (Fig. 11.5). While a significant rise is projected for annual mean rainfall, a moderate increase is projected for the winter precipitation over the HKH. The increase in annual mean precipitation could be in part due to overall summertime increase in projected precipitation in the CMIP models, which is also consistent with CORDEX simulation (Sanjay et al. 2017). The projected changes are in general, less than $12 \%$ for the near future under the RCP4.5 scenario. The differences in pattern and amount of projected precipitation by end of the twenty-first century, following RCP4.5, show similar changes as those of near future changes projected under RCP8.5, with an increase of about $16 \%$ over the north-eastern areas of the HKH. Highresolution CORDEX and NEX simulations show value additions in capturing the precipitation variability, as compared to the coarse-resolution CMIP5 models (Kapnick et al. 2014; Singh et al. 2017; Sanjay et al. 2017).

\subsubsection{Projected Changes in Temperature and Precipitation Extremes}

Future changes in temperature and precipitation extremes over the HKH based on the indices, such as (a) Maximum of daily maximum temperature (TXx), (b) Minimum of daily minimum temperature (TNn), (c) Annual total precipitation when the daily amount exceeds the 95th percentile of wet-day precipitation (R95p), (d) Maximum consecutive 5-day precipitation (RX5day) based on the RCP4.5 and RCP8.5 scenarios, relative to 1976-2005, are presented in Fig. 11.6.

The projected changes of both TXx and TNn over the $\mathrm{HKH}$ indicate a tendency for extreme warm days and extreme cold nights to become warmer in the future, with a significant increase in TNn compared to TXx. The maxima of TXx is projected to increase by $2.8{ }^{\circ} \mathrm{C}\left(3.4^{\circ} \mathrm{C}\right)$ under $\mathrm{RCP} 4.5(\mathrm{RCP} 8.5)$ in the near future, $4.0^{\circ} \mathrm{C}\left(5.2^{\circ} \mathrm{C}\right)$ by the end of twenty-first century, respectively (Fig. 11.6: middle panel). The north-western part of the HKH region is projected to experience substantial increases of TXx compared to other areas, while pronounced warming in TNn is projected over the Eastern Himalaya and TP. In particular, changes in TNn are projected to increase by as much as $5.5^{\circ}$ $\mathrm{C}$ in the Eastern Himalayas and TP under the RCP8.5 scenario by the end of twenty-first century, with relatively larger spread in RCP8.5 as compared to RCP4.5.

Future projected changes in precipitation extremes show significant increases of R95p in both RCP4.5 and RCP8.5, indicating the enhanced likelihood of occurrence of extreme precipitation over the HKH. In particular, a substantial increase in R95p is projected over the central Himalayas during the twenty-first century. The maximum consecutive 5-day precipitation (RX5day) also shows a general rise indicative of the future intensification of precipitation extremes. The changes in extreme indices over HKH are summarised in Table 11.2. In general, the MME medians under RCP8.5 are larger as compared to those of RCP4.5, especially for the temperature extremes. For changes in mean precipitation, the projected median change over the $\mathrm{HKH}$ is positive with large inter-model spread.

\subsection{Implications of Climate Change for Himalayan Snow and Glacier Mass}

Increase of temperature and changes in precipitation patterns over the HKH region is a major concern for the health of the Himalayan snow cover and glaciers. This region has experienced significant melting of snow and retreat of glaciers during the past five decades (Kulkarni and Karyakarte 2014). While global climate change significantly affects the environment over the high mountain regions of Asia, its impact on the Himalayan cryosphere is a major threat to the regional water resources (ICIMOD 2007, 2011; Armstrong 2011). In addition to global warming, the absorbing aerosols at high elevations can also enhance the warming rate and indirectly amplify the melting of snowpacks and glaciers (Ramanathan and Carmichael 2008). Significant decrease of wintertime snow over the HKH region in the recent decades is evident from the MODIS satellite snow products which affect the river flow regimes and water resources availability (Maskey et al. 2011). Satellite observations of snow cover area (NSIDC) over the HKH show large variability during the historical period (1980-2018), with moderate decline since 2000 (Fig. 11.5: bottom panel) which is consistent with MODIS analysis. Analysis of CMIP5 projections indicates decrease of annual average snow over the HKH throughout the twenty-first century, with large inter-model spread (Fig. 11.5: bottom panel).

Heavy precipitation over the Western Himalayas (WH), during the winter and early spring, is strongly linked to the activity of western disturbances (WD) (Krishnan et al. 2019a, b). High-resolution climate model projections suggest that increasing amplitude variations of the WD in warming world can favour enhancement of wintertime precipitation over the Karakoram and WH (Fig. 11.7) and provide a plausible explanation for stable snow/glacier mass in the Karakoram 


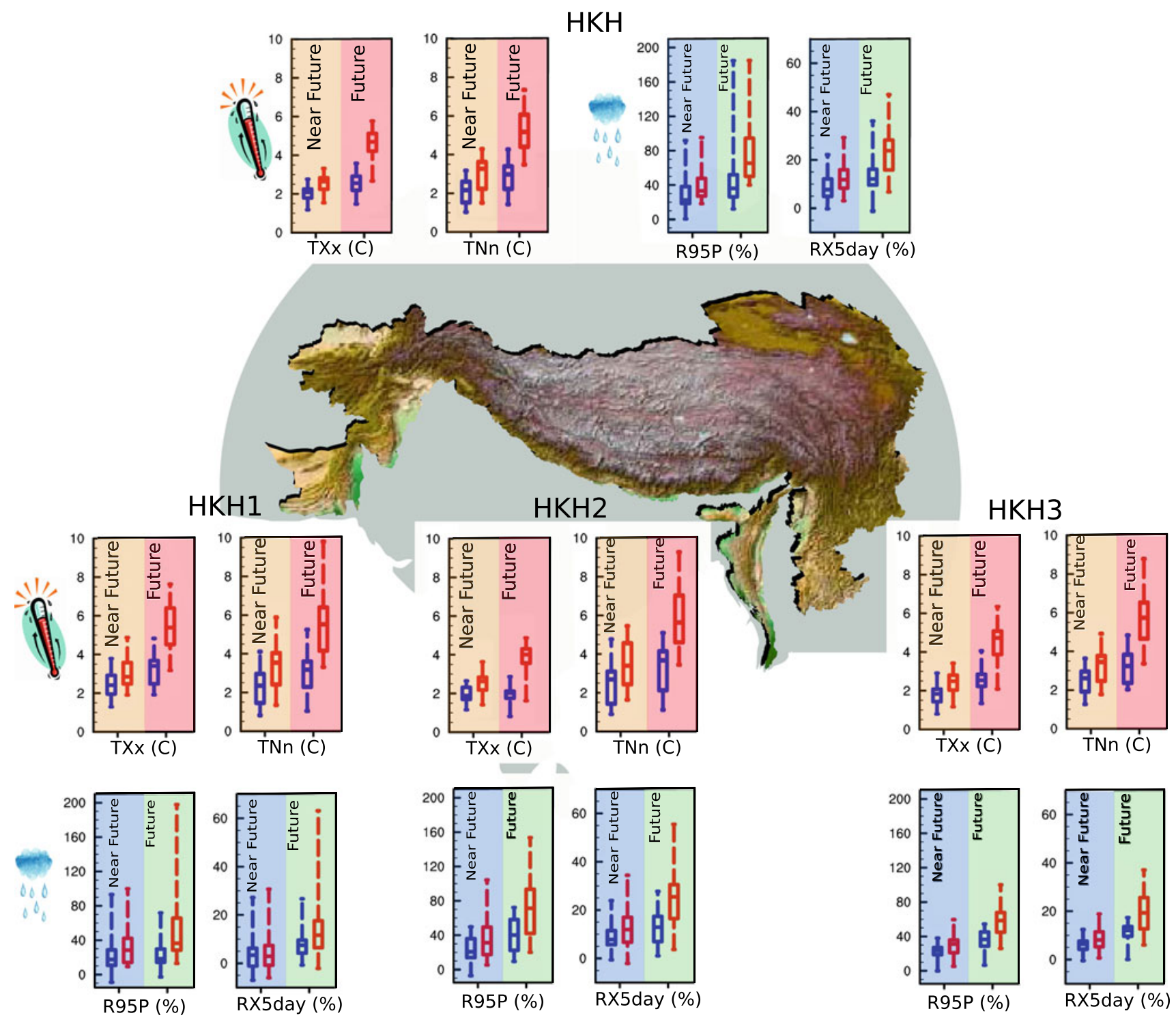

Fig. 11.6 Projected changes in temperature in ${ }^{\circ} \mathrm{C}$ (yellow and pink) and precipitation in \% (blue and green) extremes over $\mathrm{HKH}$ and its three sub-regions (as shown in Fig. 11.1) from CMIP5 models.

from RCP4.5 (blue colour) and RCP8.5 (red colour). The ranges between the 25 th and 75 th quantiles are indicated by boxes, the MME medians are indicated by the horizontal lines within boxes, and the Changes with respect to present-day mean are shown as box whiskers extreme ranges of models are indicated by whiskers

Table 11.2 Projected changes in extreme indices over HKH represented by the MME median for near and far future relative to 1976-2005, under the RCP4.5 and RCP8.5 scenarios from CMIP5 projections

\begin{tabular}{l|l|l|l|l}
\hline Indices & Near future & Far future & \\
\cline { 2 - 5 } & RCP4.5 & RCP8.5 & RCP4.5 & RCP8.5 \\
\hline TXx $\left({ }^{\circ} \mathrm{C}\right)$ & 2.2 & 2.8 & 2.7 & 4.8 \\
\hline TNn $\left({ }^{\circ} \mathrm{C}\right)$ & 2.3 & 3.3 & 3.0 & 5.1 \\
\hline R95p (\%) & 22 & 32 & 33 & 62 \\
\hline RX5day $(\%)$ & 8 & 12 & 13 & 24 \\
\hline
\end{tabular}



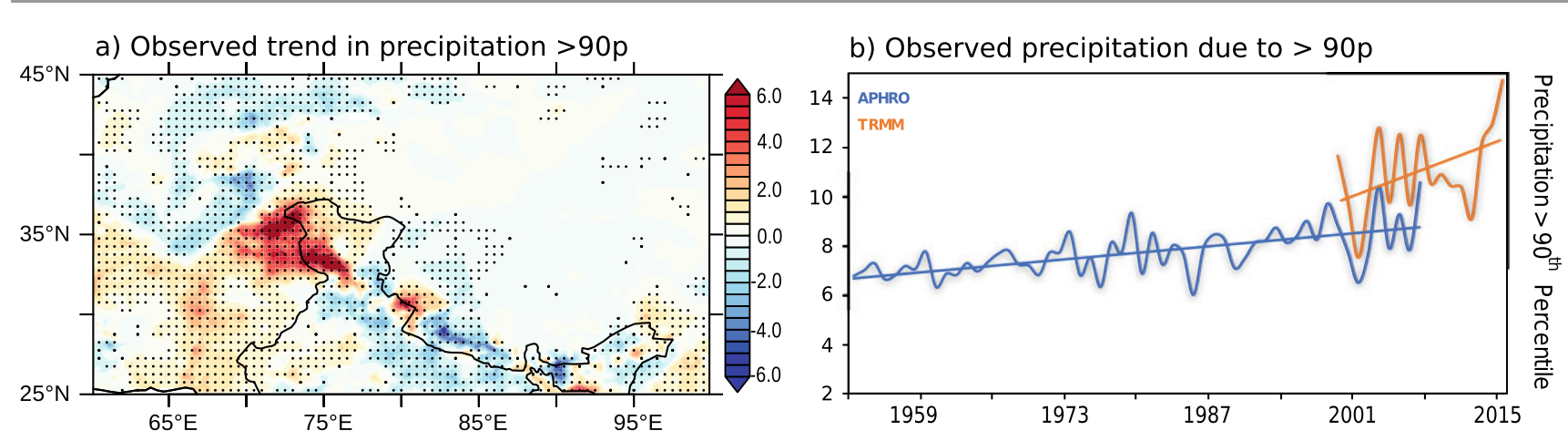

c) Simulated precipitation due to $>90 p$

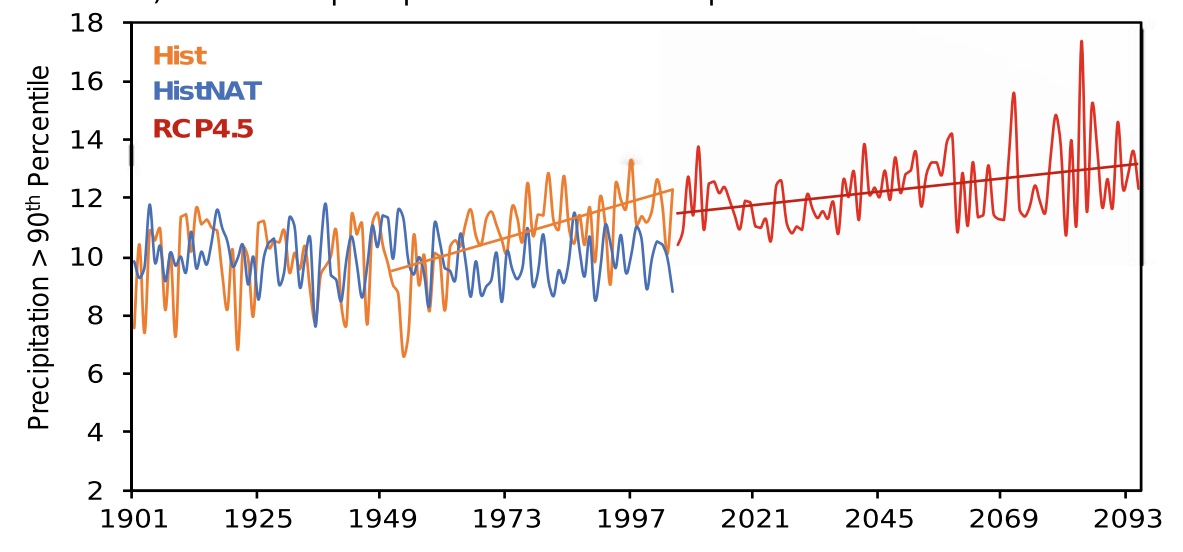

Fig. 11.7 a Spatial map of trend in daily precipitation (APHRODITE) exceeding the 90th percentile. $\mathbf{b}$ Time series of interannual variations of daily precipitation exceeding 90th percentile over HKH1 from APHRODITE and TRMM datasets. $\mathbf{c}$ Is same as b but from LMDZ simulation. Dotted areas are trends exceeding 95\% confidence level based on Mann-Kendall test. Reprinted with permission from Krishnan et al. (2019a)

by $12.6 \pm 7.5 \%$ for the past 40 years based on a detailed analysis of 83 glaciers utilising remote sensing and in situ observations. They further reported maximum loss of glacier extent in the Eastern Himalaya, near the Tista and Mt. Everest region, followed by Bhutan and Western Himalayas, with minimum loss over the Karakoram Himalayas (Brahmbhatt et al. 2015).

Glacier inventory estimated from satellite images, topographical maps and aerial photographs provides information about 9040 glaciers covering an area of $18,528 \mathrm{~km}^{2}$ in the HKH region (Sangewar and Shukla 2009; Sangewar and Kulkarni 2010). An illustration of glacier retreat between 1960 and 2000 from Kulkarni and Karyakarte (2014) is shown in Fig. 11.8. They further showed that the retreat of the Himalayan glaciers ranges from a few metres to almost $61 \mathrm{~m} \mathrm{year}^{-1}$, depending on the terrain and meteorological parameters (Kulkarni and Karyakarte 2014). Mapping of nearly 20,060 out of $\sim 40,000 \mathrm{~km}^{2}$ of glaciated area, distributed in all major climatic zones of the Himalayas, suggests a loss in glacier area by about $13 \%$ during the last four decades (Kulkarni et al. 2017). Using a high-resolution cryospheric-hydrological model, Lutz et al. (2014) quantified the run-off of hydrological regimes of major Himalayan 
a) Amount of glacial retreat

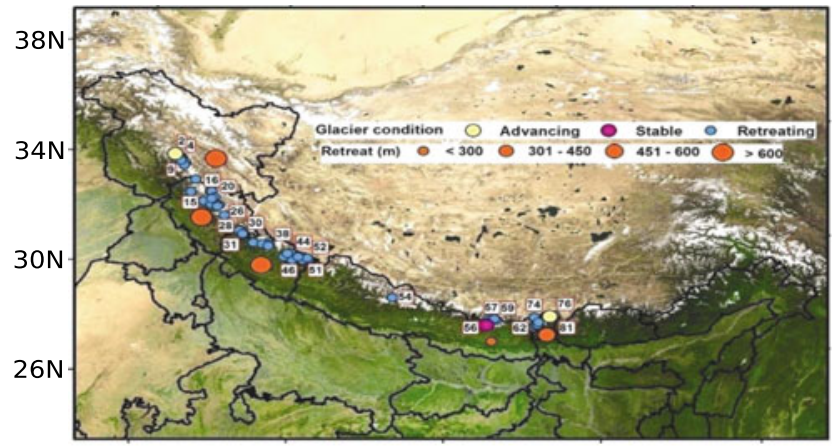

b) Glacial area loss (\%)

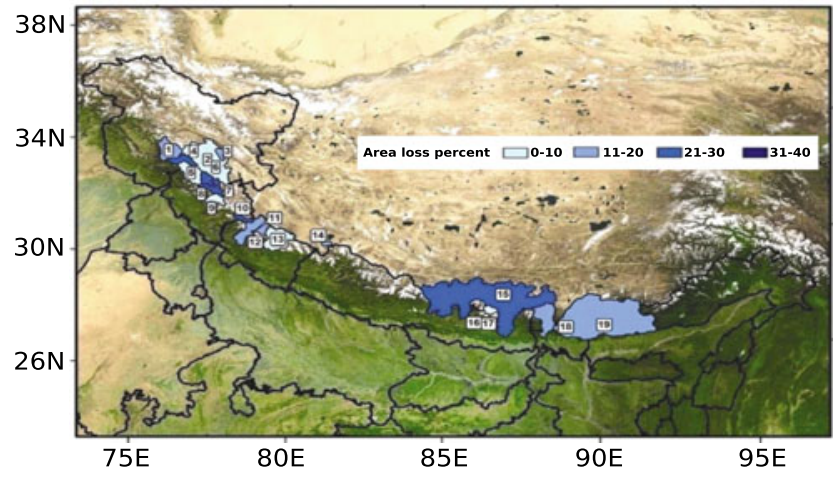

Fig. 11.8 a Amount of glacial retreat between 1960 and 2000 . b Glacial area loss in different regions of the Himalaya from 1960 to 2000. The number represents names of glaciers/basins/regions as given in Tables 1 and 2 of Kulkarni and Karyakarte (2014). From Kulkarni and Karyakarte (2014)

river basins (Indus, Ganges, Brahmaputra, Salween and Mekong rivers) for the near future following the moderate RCP4.5 scenario. Despite differences in run-off composition, they noted an increase in the projected run-off by 2050 caused primarily by an increase in precipitation in the upper Ganges, Brahmaputra, Salween and Mekong Basins and from the accelerated glacier melt in the upper Indus Basin (Fig. 1 in Lutz et al. 2014).

Integrated glaciological studies in the Chandra River basin, located in the monsoon-arid transition zone of the Upper Indus, led by the National Centre for Polar and Ocean Research (NCPOR) have provided valuable information for understanding glacier retreat and its variability in the Western Himalayas. As part of this activity, a detailed glacier mass/energy/water balance of five glaciers, viz. Sutri Dhaka, Batal, Bara Shigri, Samundra Tapu and Gepang, has been studied since 2014. While these glaciers are in similar geographical disposition, they exhibit comparatively different characteristics such as debris cover, aspect and size. The glaciers with high debris cover and varying thickness (e.g. Batal Glacier) revealed low surface melting under debris cover, as compared to clean ice and thin debris-covered ice (e.g. Sutri Dhaka) (Sharma et al. 2016). The thickness (2$100 \mathrm{~cm}$ ) of debris has attenuated melting rates up to $70 \%$ of total melting, and debris cover of $<2 \mathrm{~cm}$ thickness has accelerated melting up to $10 \%$ of the total melting (Patel et al. 2016). Further, the role of air temperature was evident with higher melting rate ( $\sim 80 \%$ of total yearly melt) during the short summers (Pratap et al. 2019). Moisture source for precipitation over the study region is dominantly $(>70 \%)$ derived from the Mediterranean regions by western disturbances (WDs) during winter and early spring, with minor $(<20 \%)$ contributions from the Indian Summer Monsoon (ISM) during the summer monsoon season (June-September). A three-component hydrograph separation based on oxygen isotope fingerprinting and field-based ablation measurements for one of the glacier basin (Sutri Dhaka) revealed that glacier ice melting is the dominant $(65-80 \%)$ contributor to the river water, followed by snow melt (20$35 \%$ ) (Singh et al. 2019). Spatial mass balance gradient varied with specific glacier's location and topography. Results of six years (2014-19) of in situ mass balance observation by NCPOR in this basin show a dominantly negative mass balance $(-0.45 \pm 0.09$ to $-1.37 \pm 0.27 \mathrm{~m}$ water equivalent per year), with the glacier snout retreating at a rate of 13-33 m per year (NCPOR, unpublished data).

It is noteworthy to mention that regions in the Karakoram Himalayas have experienced relatively stable glacier behaviour in recent decades, as opposed to glacier shrinkage observed in many other places (Hewitt 2005; Gardelle et al. 2012; Kapnick et al. 2014; Kääb et al. 2015; Forsythe et al. 2017). Climate model simulations indicate that changes in non-monsoonal wintertime frozen precipitation over the Karakoram Himalayas appear to possibly shield this region from significant glacier thickness losses under warming climate (Kapnick et al. 2014; Kääb et al. 2015; Krishnan et al. 2019a). Robust assessments of future projections of precipitation and snowfall over the Western and Karakoram Himalayas need further research given the inherent complexities of the $\mathrm{HKH}$ region and large uncertainties in model projections over this region (Forsythe et al. 2017; Ridley et al. 2013).

\subsection{Knowledge Gaps}

The accelerated anthropogenic warming over this ice-covered mountain peaks and valleys of the HKH have profound impacts such as loss in glacier mass and snow cover which can directly affect agriculture food production. Enhanced glacier mass loss can cause increased streamflow and flooding of the Himalayan river basins, and further affect downstream agricultural activity. Current generation climate models and downscaling methodologies have limitations in capturing the observed hydroclimatic variations of the Himalayan river basins (Hasson et al. 2014, 2018). Increases in snowmelt can also result from deposition of 


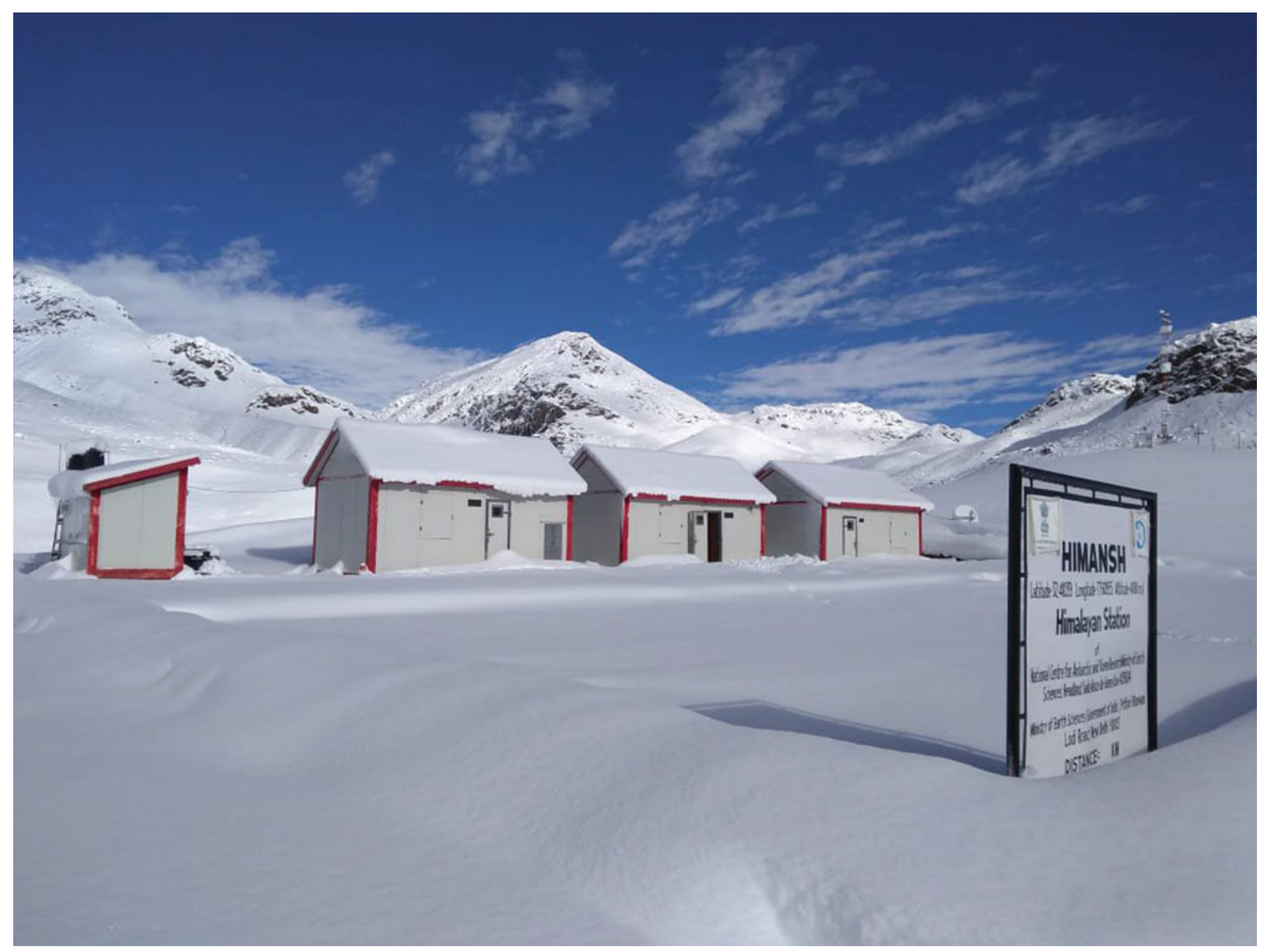

Fig. 11.9 HIMANSH: high-altitude observatory of NCPOR, MoES, during a typical Himalayan winter

light-absorbing aerosols (e.g. black carbon) over snowcovered regions, which causes warming by reducing surface albedo (Bond et al. 2013; Lau et al. 2018; Lau and Kim 2010). However, the climatic effects of black carbon on the Himalayan glaciers are not adequately understood, in part due to the large spatio-temporal variability of black carbon in the region (Kopacz et al. 2011, Chap. 5).

Long-term monitoring of weather and climate in the complex and rugged terrain of the Himalayan cryosphere is essential to fill information gaps in the region and to better represent the regional cyrospheric processes in climate models. Towards this end, the National Centre for Polar and Ocean Research (NCPOR) of the Ministry of Earth Sciences (MoES) has set up a high-altitude station named "HIMANSH" in Spiti at an altitude of 13,500 feet (Fig. 11.9).

\subsection{Summary}

In summary, human-induced climate change has led to accelerated warming of the Himalayas and the Tibetan Plateau at a rate of $0.2{ }^{\circ} \mathrm{C}$ per decade during 1951-2014. High-elevation areas (altitude $>4 \mathrm{~km}$ ), in particular, underwent amplified warming at a rate of about $0.5^{\circ} \mathrm{C}$ per decade. Many areas in the HKH, except the high-elevation Karakoram Himalayas, experienced significant decline in wintertime snowfall and glacier retreat in recent decades. Future warming in the HKH region, which is projected to be in the range of $2.6-4.6{ }^{\circ} \mathrm{C}$ by the end of the twenty-first century, will further exacerbate the snowfall and glacier decline leading to profound hydrological and agricultural impacts in the region. 


\section{References}

Archer DR, Fowler H (2004) Spatial and temporal variations in precipitation in the Upper Indus Basin, global teleconnections and hydrological implications. Hydrol Earth Syst Sci 8(1):47-61

Armstrong RL (2011) The glaciers of the Hindu Kush-Himalayan region: a summary of the science regarding glacier melt/retreat in the Himalayan, Hindu Kush, Karakoram, Pamir, and Tien Shan mountain ranges. ICIMOD, Kathmandu

Barlow M, Matthew W, Bradfield L, Heidi C (2005) Modulation of daily precipitation over southwest Asia by the Madden-Julian Oscillation. Mon Weather Rev 133(12):3579-3594

Bhutiyani MR, Vishwas SK, Pawar NJ (2007) Long-term trends in maximum, minimum and mean annual air temperatures across the northwestern Himalaya during the twentieth century. Clim Change 85:59-177

Bhutiyani MR, Kale VS, Pawar NJ (2009) Climate change and the precipitation variations in the northwestern Himalaya: 1866-2006. Int J Climatol 30(4):535-548

Bolch T et al (2012) The state and fate of Himalayan glaciers. Science 336(6079):310-314. https://doi.org/10.1126/science.1215828

Bond TC et al (2013) Bounding the role of black carbon in the climate system: a scientific assessment. J Geophys Res Atmos. https://doi org/10.1002/jgrd.50171

Bookhagen B, Burbank DW (2006) Topography, relief, and TRMM-derived rainfall variations along the Himalaya. Geophys Res Lett 33(8)

Boos W, Kuang Z (2010) Dominant control of the South Asian monsoon by orographic insulation versus plateau heating. Nature 463:218-222. https://doi.org/10.1038/nature08707

Borgaonkar HP, Ram S, Sikder AB (2009) Assessment of tree-ring analysis of high-elevation Cedrus deodara D. Don from western Himalaya (India) in relation to climate and glacier fluctuations. Dendrochronologia 27(1):59-69

Brahmbhatt R, Bahuguna I, Rathore B, Singh S, Rajawat A, Shah R, Kargel J (2015) Satellite monitoring of glaciers in the Karakoram from 1977 to 2013: an overall almost stable population of dynamics glaciers. Cryosphere Discuss 9:1555-1592. https://doi.org/10.5194/ tcd-9-1555-2015

Branstator G (2002) Circumglobal teleconnections, the jet stream waveguide, and the North Atlantic Oscillation. J Climate 15:18931910. https://doi.org/10.1175/1520-0442(2002)015\%3c1893: CTTJSW\%3e2.0.CO;2

Cannon F, Carvalho LMV, Jones C, Bookhagen B (2015) Multi-annual variations in winter westerly disturbance activity affecting the Himalaya. Clim Dyn 44:441-455. https://doi.org/10.1007/s00382$014-2248-8$

Cannon F, Carvalho LMV, Jones C, Hoell A, Norris J, Kiladis GN et al (2017) The influence of tropical forcing on extreme winter precipitation in the western Himalaya. Clim Dyn 48(3):1213-1232

Chakraborty A, Nanjundiah RS, Srinivasan J (2006) Theoretical aspects of the onset of Indian summer monsoon from perturbed orography simulations in a GCM. Ann Geophys 24:2075-2089

Choi $G$ et al (2009) Changes in means and extreme events of temperature and precipitation in the Asia-Pacific Network region, 1955-2007. Int J Climatol 29(13):1906-1925

Diaz HF, Markgraf V (2000) El Niño and the Southern Oscillation: multiscale variability and global and regional impacts. Cambridge University Press, Cambridge

Dimri A, Dash SK (2012) Wintertime climatic trends in the Western Himalayas. Clim Change 111:775-800
Dimri AP, Niyogi D, Barros AP, Ridley J, Mohanty UC, Yasunari T et al (2015) Western disturbances: a review. Rev Geophys 53 (2):225-246

Forsythe N, Fowler HJ, Li X-F, Blenkinsop S, Pritchard D (2017) Karakoram temperature and glacial melt driven by regional atmospheric circulation variability. Nat Clim Change 7(9). https:// doi.org/10.1038/nclimate3361

Gardelle J, Berthier E, Arnaud Y (2012) Slight mass gain of Karakoram glaciers in the early twenty-first century. Nat Geosci 5(5):322-325. https://doi.org/10.1038/NGEO1450

Godin L et al (1999) High strain zone in the hanging wall of the Annapurna detachment, central Nepal Himalaya. In: MacFarlane A, Sorkhabi RB, Quade J (eds) Himalaya and Tibet: mountain roots to mountain tops, 328. GSA, p 201

Hasson S, Lucarini V, Pascale S (2013) Hydrological cycle over South and Southeast Asian river basins as simulated by PCMDI/CMIP3 experiments. Earth Syst Dyn 4(2):199-217. https://doi.org/10.5194/ esd-4-199-2013

Hasson S, Lucarini V, Khan MR, Petitta M, Bolch T, Gioli G (2014) Early 21st century snow cover state over the western river basins of the Indus river system. Hydrol Earth Syst Sci 18(10):4077-4100

Hasson SU, Böhner J, Chishtie F (2018) Low fidelity of CORDEX and their driving experiments indicates future climatic uncertainty over Himalayan watersheds of Indus basin. Clim Dyn. https://doi.org/10. 1007/s00382-018-4160-0

Hewitt K (2005) The Karakoram anomaly? Glacier expansion and the 'elevation effect,' Karakoram Himalaya. Mt Res Dev 25(4):332340

Hunt KMR, Turner AG, Shaffrey LC (2018) The evolution, seasonality and impacts of western disturbances. Q J R Meteorol Soc. https:// doi.org/10.1002/qj.3200

ICIMOD (2007) The melting Himalayas: regional challenges and local impacts of climates change on mountain ecosystems and livelihoods. Technical paper X. International Centre for Integrated Mountain Development, Kathmandu, 33 pp

ICIMOD (2011) The status of glaciers in the Hindu Kush-Himalayan region. International Centre for Integrated Mountain Development, Kathmandu

Immerzeel WW, Droogers P, Jong SMD, Bierkens MFP (2009) Large-scale monitoring of snow cover and runoff simulation in Himalayan river basins using remote sensing. Remote Sens Environ 113(1):40-49

Immerzeel WW, Beek LPH, Bierkens MFP (2010) Climate change will affect the Asian water towers. Science 328. https://doi.org/10.1126/ science. 1183188

IPCC (2007) In: Solomon S, Qin D, Manning M, Chen Z, Marquis M, Averyt KB et al (eds) Climate change 2007: the physical science basis. Contribution of working group I to the fourth assessment report of the Intergovernmental Panel on Climate Change. Cambridge University Press, Cambridge, New York, p 996

IPCC (2013) Climate change. The physical science basis. Work group contribution to the IPCC fifth assessment report (AR5). Intergovernmental Panel on Climate Change, Stockholm, Sweden

IPCC SR (2019) IPCC SR ocean and cryosphere in a changing climate, Chap 2. In: Hock R et al (eds) High mountain areas

Kääb A, Treichler D, Nuth C, Berthier E (2015) Brief communication: contending estimates of 2003-2008 glacier mass balance over the Pamir-Karakoram-Himalaya. Cryosphere 9(2):557-564. https:// doi.org/10.5194/tc-9-557-2015

Kapnick SB, Delworth TL, Ashfaq M, Malyshev S, Milly PCD (2014) Snowfall less sensitive to warming in Karakoram than in Himalayas due to a unique seasonal cycle. Nat Geosci 7:834-840 
Kious WJ, Tilling RI (1996) This dynamic earth: the story of plate tectonics. USGS report. https://doi.org/10.3133/7000097

Klein Tank AMG, Peterson TC, Quadir DA et al (2006) Changes in daily temperature and precipitation extremes in central and South Asia. J Geophys Res 11116105. https://doi.org/10.1029/2005JD006316

Kopacz M, Mauzerall DL, Wang J, Leibensperger EM, Henze DK, Singh K (2011) Origin and radiative forcing of black carbon transported to the Himalayas and Tibetan Plateau. Atmos Chem Phys 11:2837-2852. https://doi.org/10.5194/acp-11-2837-2011

Krishnamurti TN, Thomas A, Simon A, Kumar V (2010) Desert air incursions, an overlooked aspect, for the dry spells of the Indian summer monsoon. J Atmos Sci 67:3423-3441

Krishnan R, Kumar V, Sugi M, Yoshimura J (2009) Internal feedbacks from monsoon-midlatitude interactions during droughts in the Indian summer monsoon. J Atmos Sci 66:553-578

Krishnan R, Sabin TP, Ayantika DC, Kitoh A, Sugi M, Murakami H et al (2013) Will the South Asian monsoon overturning circulation stabilize any further? Clim Dyn 40(1-2):187-211. https://doi.org/ 10.1007/s00382-012-1317-0

Krishnan R, Sabin TP, Vellore R, Mujumdar M, Sanjay J, Goswami BN et al (2016) Deciphering the desiccation trend of the South Asian monsoon hydroclimate in a warming world. Clim Dyn 47(34):1007-1027. https://doi.org/10.1007/s00382-015-2886-5

Krishnan R, Sabin TP, Madhura RK, Vellore R, Mujumdar M, Sanjay J, Nayak S, Rajeevan M (2019a) Non-monsoonal precipitation response over the Western Himalayas to climate change. Clim Dyn. https://doi.org/10.1007/s00382-018-4357-2

Krishnan R et al (2019b) Unravelling climate change in the Hindu Kush Himalaya: rapid warming in the mountains and increasing extremes. In: Wester P, Mishra A, Mukherji A, Shrestha A (eds) The Hindu Kush Himalaya assessment. Springer, Cham

Kulkarni AV, Karyakarte Y (2014) Observed changes in Himalayan glaciers. Curr Sci 106(2):237-244

Kulkarni AV, Pratibha S (2018) Assessment of glacier fluctuations in the Himalaya. In: Goel $\mathrm{P}$, Ravindra R, Chattopadhyay S (eds) Science and geopolitics of the White World. Springer, Cham

Kulkarni A, Patwardhan S, Kumar K, Ashok K, Krishnan R (2013) Projected climate change in the Hindu Kush-Himalayan region by using the high-resolution regional climate model PRECIS. Mt Res Dev 33(2):142-151

Kulkarni AV, Nayak S, Pratibha S (2017) Variability of glaciers and snow cover. In: Rajeevan M, Nayak S (eds) Observed climate variability and change over the Indian region. Springer geology. Springer, Singapore

Lang TJ, Barros AP (2004) Winter storms in the Central Himalayas. J Meteorol Soc Japan 82:829-844

Lau WKM, Kim KM (2010) Fingerprinting the impacts of aerosols on long-term trends of the Indian summer monsoon regional rainfall. Geophys Res Lett 37(16):L16705. https://doi.org/10.1029/ 2010GL043255

Lau WKM, Sang J, Kim MK, Kim KM, Koster RD, Yasunari TJ (2018) Impacts of aerosol snow darkening effects on hydro-climate over Eurasia during boreal spring and summer. J Geophys Res Atmos 123:8441-8461. https://doi.org/10.1029/2018JD028557

Liu X, Yin ZY, Shao X, Qin N (2006) Temporal trends and variability of daily maximum and minimum, extreme temperature events, and growing season length over the eastern and central Tibetan Plateau during 1961-2003. J Geophys Res Atmos 111(D19):4617-4632

Liu X, Cheng Z, Yan L et al (2009) Elevation dependency of recent and future minimum surface air temperature trends in the Tibetan Plateau and its surroundings. Glob Planet Change 68:164-174

Lutz AF, Immerzeel WW, Shrestha AB, Bierkens MFP (2014) Consistent increase in High Asia's runo due to increasing glacier melt and precipitation. Nat Clim Change. https://doi.org/10.1038/ NCLIMATE2237

Madden R, Julian P (1971) Detection of a 40-50-day oscillation in the zonal wind in the tropical Pacific. J Atmos Sci 28:702-708

Madhura RK, Krishnan R, Revadekar JV, Mujumdar M, Goswami BN (2015) Changes in western disturbances over the Western Himalayas in a warming environment. Clim Dyn 44:1157-1168. https://doi.org/10.1007/s00382-014-2166-9

Maskey S, Uhlenbrook S, Ojha S (2011) An analysis of snow cover changes in the Himalayan region using MODIS snow products and in-situ temperature data. Clim Change 108:391-400

Nan S, Zhao P, Yang S, Chen J (2009) Springtime tropospheric temperature over the Tibetan Plateau and evolution of the tropical Pacific SST. J Geophys Res Atmos 114(10). https://doi.org/10. 1029/2008jd011559

Negi HS, Neha K, Shekhar MS, Ganju A (2018) Recent wintertime climatic variability over the North West Himalayan cryosphere. Curr Sci 114(4):25

Panagiotopoulos F, Shahgedanova M, Stephenson DB (2002) A review of Northern Hemisphere winter time teleconnection patterns. J Phys IV France 12(10):27. https://doi.org/10.1051/jp4:20020450

Pant GB, Pradeep Kumar P, Revadekar JV, Singh N (2018) Climate change in the Himalayas. Springer. https://doi.org/10.1007/978-3319-61654-4

Patel LK, Sharma P, Thamban M, Singh A, Ravindra R (2016) Debris control on glacier thinning - a case study of the Batal glacier, Chandra basin, Western Himalaya. Arab J Geosci 9(4):309. https:// doi.org/10.1007/s12517-016-2362-5

Pepin N et al (2015) Elevation-dependent warming in mountain regions of the world. Nat Clim Change 5:424-430

Pratap B, Sharma P, Patel L, Singh AT, Gaddam VK, Oulkar S, Thamban M (2019) Reconciling high glacier surface melting in summer with air temperature in the semi-arid zone of Western Himalaya. Water 11:1561. https://doi.org/10.3390/w11081561

Rai SC, Gurung CP (2005) An overview of glaciers, glacier retreat and subsequent impacts in Nepal, India and China. WWF Program. http://assets.panda.org/downloads/himalayaglaciersreport2005.pdf

Rajbhandari R, Shrestha AB, Kulkarni A et al (2015) Projected changes in climate over the Indus river basin using a high resolution regional climate model (PRECIS). Clim Dyn 44:339. https://doi.org/10. 1007/s00382-014-2183-8

Rajbhandari R, Shrestha AB, Nepal S, Wahid S (2016) Projection of future climate over the Koshi River basin based on CMIP5 GCMs. Atmos Clim Sci 6:190-204. https://doi.org/10.4236/acs.2016.62017

Ramanathan V, Carmichael G (2008) Global and regional climate changes due to black carbon. Nat Geosci 1(4):221

Rashul G (2014) Food, water, and energy security in South Asia: a nexus perspective from the Hindu Kush Himalayan region. Environ Sci Policy 39:35. https://doi.org/10.1016/j.envsci.2014.01.010

Rees HG, Collins DN (2006) Regional differences in response of flow in glacier-fed Himalayan rivers to climatic warming. Hydrol Process 20(10):2157-2169

Ren YY, Parker D, Ren GY, Dunn R (2015) Tempo-spatial characteristics of sub-daily temperature trends in mainland China. Clim Dyn 46(9-10):2737-2748. https://doi.org/10.1007/s00382-015-2726-7

Ren YY, Ren GY, Sun XB, Shrestha AB, You QL, Zhan YJ et al (2017) Observed changes in surface air temperature and precipitation in the Hindu Kush Himalayan region during 1901-2014. Adv Clim Change Res 8(3). https://doi.org/10.1016/j.accre.2017. 08.001

Ridley J, Wiltshire A, Mathison C (2013) More frequent occurrence of westerly disturbances in Karakoram up to 2100. Sci Total Environ 468-469:S31-S35 
Sabin TP et al (2013) High resolution simulation of the South Asian monsoon using a variable resolution global climate model. Clim Dyn 41:173-194

SAC (2016) Monitoring snow and glaciers of Himalayan region. Space Applications Centre, ISRO, Ahmedabad, p 413. ISBN 978-93-82760-24-5

Saji NH, Goswami BN, Vinayachandran PN et al (1999) A dipole mode in the tropical Indian Ocean. Nature 401(23):360-363

Sangewar CV, Kulkarni A (2010) Observational studies of the recent past, report of the study group on Himalayan glaciers. Prepared for Principal Scientific Advisor Government of India

Sangewar CV, Shukla SP (2009) Inventory of Himalayan glaciers (an updated edition). Special publication no. 34. Geological Survey of India

Sanjay J, Krishnan R, Shrestha AB, Rajbhandari R, Ren GY (2017) Downscaled climate change projections for the Hindu Kush Himalayan region using CORDEX South Asia regional climate models. Adv Clim Change Res 8(3):185-198. https://doi.org/10. 1016/j.accre.2017.08.003

Sharma E et al (2019) Introduction to the Hindu Kush Himalaya assessment. In: Wester P, Mishra A, Mukherji A, Shrestha AB (eds) The Hindu Kush Himalaya assessment-mountains, climate change, sustainability and people. Springer-Nature, Switzerland

Sharma P, Patel LK, Ravindra R, Singh A, Mahalinganathan K, Thamban M (2016) Role of debris cover to control specific ablation of adjoining Batal and Sutri Dhaka glaciers in Chandra Basin (Himachal Pradesh) during peak ablation season. J Earth Syst Sci 125:459. https://doi.org/10.1007/s12040-016-0681-2

Sheridan SC, Lee CC, Allen MJ, Kalkstein LS (2012) Future heat vulnerability in California, part I: projecting future weather types and heat events. Clim Change 115:291-309

Shrestha AB, Aryal R (2011) Climate change in Nepal and its impact on Himalayan glaciers. Reg Environ Change 11:S65-S77

Shrestha AB, Wake CP, Mayewski PA, Dibb JE (1999) Maximum temperature trends in the Himalaya and its vicinity: an analysis based on temperature records from Nepal for the period 1971-94. J Clim 12:2775-2786

Shrestha AB, Devkota LP, John D et al (2010) Climate change in the Eastern Himalayas: observed trends and model projections. Climate change impact and vulnerability in the EH-technical report 1

Shrestha AB, Agrawal NK, Alfthan B, Bajracharya SR, Maréchal J, Van Oort B (2015) The Himalayan climate and water atlas: impact of climate change on water resources in five of Asia's major river basins. GRID-Arendal and CICERO, ICIMOD

Singh S, Ghosh S, Sahana AS, Vittal H, Karmakar S (2017) Do dynamic regional models add value to the global model projections of Indian monsoon? Clim Dyn 48(3-4):1375-1397. https://doi.org/ 10.1007/s00382-016-3147-y

Singh AT, Rahaman W, Sharma P, Laluraj CM, Patel LK, Pratap B, Gaddam VK, Thamban M (2019) Moisture sources for precipitation and hydrograph components of the Sutri Dhaka Glacier Basin, Western Himalayas. Water 11:2242. https://doi.org/10.3390/ w11112242

Srivastava P, Misra DK (2012) Optically stimulated luminescence chronology of terrace sediments of Siang River, Higher NE Himalaya: comparison of quartz and feldspar chronometers. J Geol Soc India 79:252-258
Sun XB, Ren GY, Shrestha AB, Ren YY, You QL, Zhan YJ et al (2017) Changes in extreme temperature events over the Hindu Kush Himalaya during 1961-2015. Adv Clim Change Res 8(3):157-165. https://doi.org/10.1016/j.accre.2017.07.001

Thompson DWJ, Wallace JM (1998) The Arctic Oscillation signature in the wintertime geopotential height and temperature fields. Geophys Res Lett 25:1297-1300

Thompson LG, Mosley-Thompson E, Davis ME, Lin PN, Henderson K, Mashiotta TA (2003) Tropical glacier and ice core evidence of climate change on annual to millennial time scales. Clim Change 59 (1-2):137-155

Turner A, Annamalai H (2012) Climate change and the South Asian summer monsoon. Nat Clim Change 2:587-595. https://doi.org/10. 1038/nclimate1495

Van Vuuren DP, Edmonds J, Kainuma M, Riahi K, Thomson A, Hibbard K et al (2011) The representative concentration pathways: an overview. Clim Change 109(1):5-31

Vellore R, Krishnan R, Pendharkar J, Choudhury AD, Sabin TP (2014) On anomalous precipitation enhancement over the Himalayan foothills during monsoon breaks. Clim Dyn 43(7):2009-2031. https://doi.org/10.1007/s00382-013-2024-1

Wallace JM (2000) North Atlantic oscillatiodannular mode: two paradigms - one phenomenon. Q J R Meteorol Soc 126:791-805. https://doi.org/10.1002/qj.49712656402

Wester P, Mishra A, Mukherji A, Shrestha AB (eds) (2019) The Hindu Kush Himalaya assessment-mountains, climate change, sustainability and people. Springer-Nature, Switzerland

Wu J, Xu Y, Gao X-J (2017) Projected changes in mean and extreme climates over Hindu Kush Himalayan region by 21 CMIP5 models. Adv Clim Change Res 8(3):176-184. https://doi.org/10.1016/j. accre.2017.03.001

Xu J, Shrestha AB, Vaidya R, Eriksson M, Nepal S, Sandstrom K (2008) The changing Himalayas. Impact of climate change on water resources and livelihoods in the greater Himalayas. ICIMOD, Kathmandu

Xu WH, Li QX, Yang S, Yan X (2014) Overview of global monthly surface temperature data in the past century and preliminary integration. Adv Clim Change Res 5(3):111-117. https://doi.org/10. 1016/j.accre.2014.11.003

Yan LB, Liu XD (2014) Has climatic warming over the Tibetan Plateau paused or continued in recent years? J Earth Ocean Atmos Sci 1:13-28

Yanai MH, Li C (1994) Mechanism of heating and the boundary layer over the Tibetan Plateau. Mon Weather Rev 122:305-323

You QL, Min J, Zhang W, Pepin N, Kang S (2015) Comparison of multiple datasets with gridded precipitation observations over the Tibetan Plateau. Clim Dyn 45:791-806

You QL, Ren GY, Zhang YQ, Ren YY, Sun XB, Zhan YJ et al (2017) An overview of studies of observed climate change in the Hindu Kush Himalayan (HKH) region. Adv Clim Change Res 8(3):141147. https://doi.org/10.1016/j.accre.2017.04.001

Zhan YJ, Ren GY, Shrestha AB, Rajbhandari R, Ren YY, Sanjay J (2017) Change in extreme precipitation events over the Hindu Kush Himalayan region during 1961-2012. Adv Clim Change Res 8(3). https://doi.org/10.1016/j.accre.2017.08.002

Zhou X, Zhao P, Chen J, Chen L, Li W (2009) Impacts of thermodynamic processes over the Tibetan Plateau on the Northern Hemispheric climate. Sci China Ser D Earth Sci 52(11):1679-1693 
Open Access This chapter is licensed under the terms of the Creative Commons Attribution 4.0 International License (http:// creativecommons.org/licenses/by/4.0/), which permits use, sharing, adaptation, distribution and reproduction in any medium or format, as long as you give appropriate credit to the original author(s) and the source, provide a link to the Creative Commons license and indicate if changes were made.
The images or other third party material in this chapter are included in the chapter's Creative Commons license, unless indicated otherwise in a credit line to the material. If material is not included in the chapter's Creative Commons license and your intended use is not permitted by statutory regulation or exceeds the permitted use, you will need to obtain permission directly from the copyright holder. 